This is a self-archived - parallel published version of this article in the publication archive of the University of Vaasa. It might differ from the original.

\title{
Examining digital government and public service provision : the case of Finland
}

Author(s): Osifo, Omoregie Charles

Title: Examining digital government and public service provision : the case of Finland

Year: $\quad 2018$

Version: Accepted manuscript

Copyright (C)2018 IEEE. Personal use of this material is permitted. Permission from IEEE must be obtained for all other uses, in any current or future media, including reprinting/republishing this material for advertising or promotional purposes, creating new collective works, for resale or redistribution to servers or lists, or reuse of any copyrighted component of this work in other works.

Please cite the original version:

Osifo, O.C., (2018). Examining digital government and public service provision : the case of Finland. In: 2018 41st International Convention on Information and Communication Technology, Electronics and Microelectronics (MIPRO), Opatija, 2018 (pp. 1342-1347). https://doi.org/10.23919/MIPRO.2018.8400242 


\title{
Examining Digital Government and Public Service Provision: The Case of Finland
}

\author{
Omoregie Charles Osifo* \\ * University of Vaasa/School of Management, Vaasa, Finland \\ Charles.osifo@uva.fi
}

\begin{abstract}
Finland is one country that has long embraced technology in many aspects of her existence. To understand the present outlook of digital government and public service provision in Finland, an evaluation is necessary. This paper explores the successes and challenges of digital government in relation to public service provision through relevant reports and by focusing on policy strategies, implementations, and innovativeness. The case of Finland revealed that digital government via the egovernment framework is vital in the areas of democracy and decision-making, health care, education, integration, security, land survey and social services provision. Areas that require improvements are collaboration, coordination, partnership building between stakeholders, funding, fiscal policies, expertise, literacy, and acceptance. In addition, is addressing the problems of data deluge and ethical dilemmas (trust), and inequality questions.
\end{abstract}

Keywords - Digital Government; egovernment; public sector; public service provision; Finland

\section{INTRODUCTION}

Digital government is part of the broader change management and new public management reform ideas. Change management is often referred to as the general strategy adopted in teaching and helping institutions, governments, groups, societies and individuals to pursue and realize change. Formulating change and implementing change in administration are two different things with unique challenges, though the latter is said to be more complex than the former (Brunsson 2009). Technological innovations of various kinds have made governance more modernized and accessible to more people at different levels (local, national and global). Growth in digital technologies such as internet services has changed the traditional models of governance. The modernizations have mainly manifested in the delivery of public services and expansion in the geographical and demographic reaches of governance.
Examining how digital government shapes public governance (formulation and implementation of public service) is evaluating the definition and principles of action, mission statement, guideline or regulatory framework (do's and don'ts), administrative and implementation aspects of tools, results, successes, challenges, and prospects. A contemporary perspective on examining the relationship that exists between citizens and governments/institutions would include ways of providing citizens with better, satisfactory, and secured services with the most comfortable costs. In addition, is examining the future of public governance (e.g. the roles of artificial intelligence in future public sectors). Finland is one the countries that have embraced technology in many aspects of their endeavors. In the past two decades, the government of Finland has invested massively in technology and innovations at both national and local levels of administration. The massive investments have mainly concerned the formulation and implementation of public policies and services through the digital government or ICT strategies. The policies of digitalization in Finland have yielded mixed outcomes. Digital government in relation to public service provision has been successful in most contexts and aspects and faced challenges in other aspects and contexts; thereby, needing improvements. According to University of Vaasa (2018), the ICT sector in Finland suffers from human capacity limitation (labor shortages), which has been identified as a major hindrance to Finland's economic growth and the development of digitalization of the Finnish society; to be specific the software industry has labor shortages of thousands of experts nationwide. Figure 1 is a representation of objective and focus of this paper.

Digitalization is using and welcoming things that have been transformed to digital forms; the digital transformation part concerns the effect(s) of digitization (Khan (2016). According to the World Economic Forum (2017), the digital revolution has transformed the traditional ways of doing things in our modern world. This transformation has also been witnessed in the areas of governance, which is now called digital government. Figure 1 is a representation of the objective outlook. 


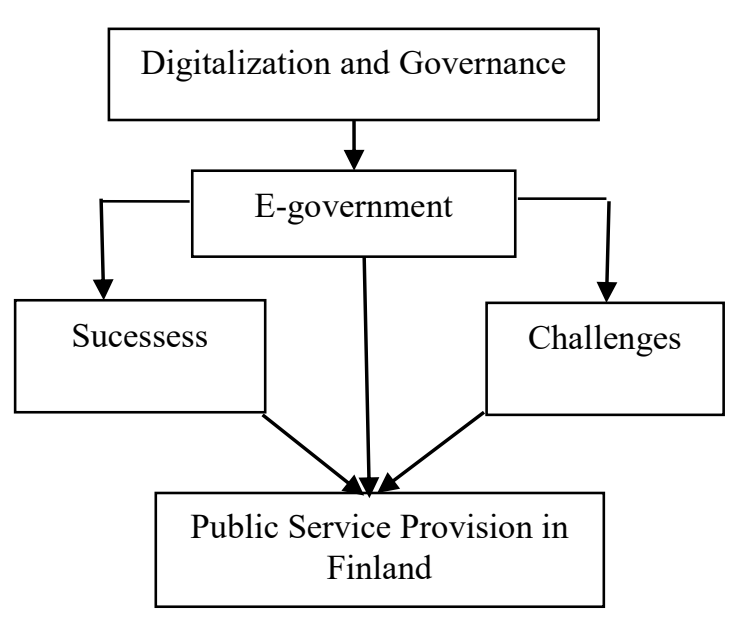

Figure1: Overview of Objective

Digital government is a more recent and broader concept in comparison to the e-government concept. The strategies of digital government and e-government are similar. However, in reviewing the concept of digital government in relation to public service provision, the egovernment framework is more encouraged, because of the availability of real cases and experience.

The key aim of this paper is to examine the contemporary outlook of digital government and public service provision in Finland via the e-government framework. The successes and challenges in Finland are explored through policy strategies, implementations, and innovativeness. The case study uses information/data from different national and international reports (desk research) as justification for analysis and evaluation of egovernment outlook in Finland. This represents the broader outlook of digital government and public service provision in Finland.

\section{REFORMS AND DIGITALIZATION IN PUBLIC SECTOR.}

Dimensions to understand the relationships between reforms and digitalization in the public sector are numerous. The popular dimensions are political and administrative dimension, economic dimension, social dimension, anti-corruption dimension, exponential technologies dimension, energy transition dimension etc. From the political and administrative dimension, we understand/study the provision of public services and ways governments and institutions relate with their citizens, because it is proven that technology is an essential part of good governance. From the economic dimension, we study/understand how human and capital growth are affected; one key question to ask in this regard could related to what is the contribution of the informal sector or activities of criminal organizations to the GDP. (OECD 2016; \& European Police Office 2017.) According to Global Security (2017), criminal networks in Italy for example contribute $20-27 \%$ to the Italian GDP. Social dimension helps us to study/understand interactions between different individuals and groups/institutions. The anti-corruption dimension helps to study/understand how digital tools could enhance or serve as solution to corrupt activities (e.g. fraud). According to Tickner (2015: 1-8), technology plays a crucial role in the fight against corruption and other unethical activities. From the exponential technology dimension, we study/understand the relevance of emerging technologies (e.g. artificial intelligence) in the future of human existence and public sector. From the energy transition dimension, we study/understand the nature, relevance and future of energy in our world (OECD 2016; \& European Police Office 2017).

Digitalization is highly reflected in all the models of New Public Management (NPM) reform ideas, which are the Market Model, Flexible Government Model, Deregulating Government Model, Participatory State Model and E-Governance Model. The market model stipulates that the assumptions of private sector model are the best ways of managing the public sector, where digital tools enhance efficiency. The participatory state model focuses on the need for democratic and collective mechanisms to be key features in governance by understanding what the public wants and finding ways toward fulfilling them; digital tools help in the realization of this objective. The flexible government model stresses the need for government and its agencies to make appropriate policy responses to environmental changes rather than just responding in their habitual ways to what are inherently novel changes; digitalization is an essential part of the change. The permanence of government, both for individual and public organisations is generally regarded as inimical to growth. At a more basic level, a flexible government is simply one that is capable of responding effectively to new challenges and of surviving in the face of changes. Deregulating government model emphasises the need for the reduction of formalised rules and regulations and the elimination of rules that would cause delay to public service functions. Therefore, the public service workers would be less controlled in carrying out the public business, because Administrative discretion becomes a relevant tool for the public service worker in the day-to-day dealings under this model.

Digital tools are vital here in helping public officers to become more flexible. E-Governance model of reform is quite a new approach in reforming the public sector. This model emphasises the adoption information and communication technologies (ICTs) in the management of public service to make it more functional by increasing growth and reducing unnecessary delay (red tape). (Simon 1997; Peters 2001; \& Riley 2003.) According to Peters (2001), the values that have informed the need for change in the management of public sectors include that of modernization, internationalization and societal/cultural advancements. 


\section{A. Definition of Digital Government and Roles in} Public Service Provision

Digital government is an idea and pattern of guaranteeing accountability and effective organization through digital procedures. Digital government has different definitions and interpretations, but central to all is the one relating to dissemination and generation of services and information within institutions/government from one perspective and between institutions/government and citizens or public from another perspective through the adoption of ICT strategies. According to Fountain (2004), digital government can be summarized as the production and delivery of services and information inside government and between government and the public, in order to formulate and implement government/public responsibilities; the two natures of government relationships that exist within this framework is government-to-citizen and government-to-government relationships. According to OECD (2016), governments in most developed countries have been urged to develop and implement digital government strategies in order to realize digital transformation; this became imperative, because of the key contribution of digital technologies as a strategic enhancer in creating open, participatory and trustworthy public sectors in improving social inclusiveness and governmental accountability, and to connect government and non-government actors and develop new approaches to add to national development and long-term sustainable growth.

The Digital government ideas have mostly manifested through the e-government framework. It is through the egovernment framework that strategies relating to digital government have been experimented in many countries. The e-government framework is most suitable, because the issue is not to introduce digital technologies into public administration (digitalization), but to integrate the use of digital technologies into public sector modernization efforts (transformative digital government) (OECD 2016:7). According to Gunter (2006), egovernment is a modernized form of government that uses solid and reliable information and communication technologies (ICT) in the provision of public services to citizens (G2C), institutions, and other relevant stakeholders. E-government is not only relevant to the public sector, but also the business sector from the angles of corporate governance, hybridity and service efficiency. According to Johnson (2002), Government to Business (G2B) services has good benefits for companies in areas of cost cutting. Through the e-government framework, relevant tools (software, hardware, applications etc.) are adopted or used to provide the relevant services; some of these tools include social media, internet and other computer and mobile technologies/applications such as evoting and e-participation tools. Special arears of public services that the e-government tools have been tested in different countries include educations services, social care and protection services, health care service, integration services, security service etc. The tools of digital government in general play different good roles in the society, but also have their unique challenges; the social media for example is good platform for information sharing between individuals and groups, but it is also an avenue through which evil, unethical and corrupt activities are executed by bad individuals/groups. Labor and financial challenges have limited the efficiency and effectiveness of digital public service provision in many nations and useful solutions are being sourced to tackle these challenges (Johnson 2007).

\section{THE CASE OF FINLAND}

Like in many countries, digital government through the e-government framework is about the provision of public services to citizens, institutions and other stakeholders in Finland. Digital government in Finland has a long history, the pioneering policies are traceable to the 1970s when ICT was considered as an essential part of good governance. However, the 1990s was considered the golden era when Finland became one of the leading information technology countries. In the 1990s, Finland was ranked topmost in internet connections per capital and technological innovations development. Numerous egovernment projects were initiated and implemented in Finland in the 1990s and the country became one of the international best practices and case study for other nations. Public service provision in Finland through the egovernment framework has been implemented in different sector. According to the Finnish Prime Minister (Mr Juha Sipilä), digitalization is high on the government program, because public services shall be developed primarily as digital; in May 2015, Finland published its National Action Plan, which is the 100th National Action Plan published under the Open Government Partnership since its creation in 2011. This being the $2^{\text {nd }}$ Action Plan for Finland, the aim was to commit the country in making online services more market oriented and focusing on the Youth participation in Government and Open Data. (OECD 2003; \& European Commission 2015.)

Key areas that digitalization has been adopted in public service provision are health care provision, social service provision, security service provision, integration service provision, and election and citizen participation services (e.g. e-voting, e-democracy, and e-participation). However, different arguments, results and prospects have followed digitalization and public service provision in Finland and to understand these more clearly, the policy successes and challenges are explored through its strategies, implementations, and innovativeness.

The strategic breakdown of digitalization into different operational areas has enhanced the effectiveness and focus in respective sectors. At the beginning of digital government policy formulation in Finland, a clear directive was issued by the Finnish Government on the need to separate digitalization between the public sector and private sector. The open government action plan has 
been another strategic success in Finland, because online services have become more citizen-friendly and youth participation in government is at the highest point. Official data of state has become more accessible to citizens/public with the inclusion of good public service provision through the government to citizens (G2C) initiatives. The successes of the policy dichotomy and open government action plan have been enhanced by the legal and ethical frameworks availability and viability. The implementations of digital government policy through the e-government framework have been successful through the development of digital tools at central, regional and local governments and institutional levels. (Ministry of Finance 2009; European Commission 2015; OECD 2003; OECD 2016; \& OECD 2017.) Table 1 shows the success outlook.

Table 1: The Success Outlook

\begin{tabular}{|c|c|}
\hline $\begin{array}{l}\text { Digital } \\
\text { Government } \\
\text { and Public } \\
\text { Service } \\
\text { Provision }\end{array}$ & Key Areas of Success \\
\hline Strategy & 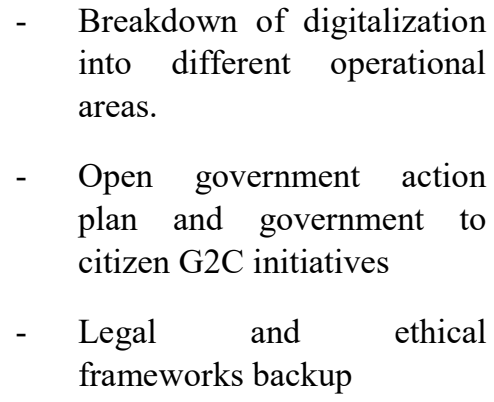 \\
\hline Implementation & $\begin{array}{l}\text { - } \begin{array}{l}\text { Development of digital tools } \\
\text { at central, regional, and local } \\
\text { governments and } \\
\text { institutional levels }\end{array} \\
\text { - } \begin{array}{l}\text { Voting and participation } \\
\text { services }\end{array} \\
\text { - } \begin{array}{l}\text { Health care and educational } \\
\text { service provisions }\end{array} \\
\text { - Security and integration } \\
\text { service provisions } \\
\text { - Social care provision and } \\
\text { land survey activities }\end{array}$ \\
\hline Inno & - $\quad$ Broadening of scope \\
\hline
\end{tabular}

Sources: Ministry of Finance (2009); European Commission (2015); OECD (2003); OECD (2016); \& OECD (2017)
The development of digital tools at different levels in Finland has helped Finnish citizens to participate in democracy and decision-making through e-voting and eparticipation services; in addition, health care (earchiving and e-prescription), education (clouding), integration, security, social care, and land survey activities have been made more accessible, transparent, convenient, effective and efficient to citizens and other stakeholders in Finland. The success of digital government policy in Finland is also characterized by its innovativeness in relation to scope broadening, because the Finnish government is presently switching to digital innovations in every sector (e.g. energy transition) and questions of artificial intelligence as part of future public sector is being answered. (Ministry of Finance 2009; European Commission 2015; OECD 2003; OECD 2016; \& OECD 2017.)

The statistical breakdown of the successes of egovernment in Finland are represented in the Eurostat (2018) evaluation report. Figure 2 is a representation of people in Finland using internet to interact with public authorities
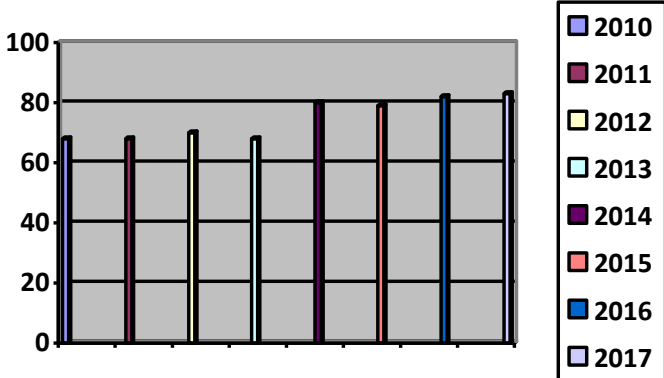

Figure 2: Individuals using the internet for interacting with public authorities (Eurostat 2018).

According to the Eurostat (2018) report, the percentage of people using the internet to interact with public authorities in Finland has grown from 68\% in 2010 to $83 \%$ in 2017 . Other statistical data to evaluate the successes of e-government in Finland is derivable from the European Commission (2015: 6) report. The report shows that the percentage of people who use the internet to obtain information from public authorities in Finland has grown from $61 \%$ in 2010 to $74 \%$ in 2015 ; the percentage of individuals using the internet for downloading official forms from public authorities in Finland has grown from $49 \%$ in 2010 to $63 \%$ in 2015 ; and the percentage of individuals using the internet for sending filled forms to public authorities in Finland has grown from $39 \%$ in 2010 to $59 \%$ in 2015 . In enhancing more, the success of e-government in Finland according to the European Commission (2015: 8) report, the Ministry of Finance and Population Register Centre have launched the Data Exchange Layer on November 18, 2015, which is premised on the Estonian X-Road model and software. The Data Exchange Layer would help to 
standardize the mode of exchanging information between public sector organizations and national datasets and in the future enables the use of other services developed in the National Architecture for Digital Services program. According to the Ministry of Finance (2009), the program on electronic service and democracy (SADe) in Finland considers the experiences of end-users of all e-services and the gap that exists between national government and municipalities. However, Challenges exist in relevant areas of e-government and public service provision. Table 2 is a representation of some of the key challenges:

Table 2: The Challenge Outlook

\begin{tabular}{|c|c|}
\hline $\begin{array}{l}\text { Digital } \\
\text { Government } \\
\text { and Public } \\
\text { Service } \\
\text { Provision }\end{array}$ & Key Areas of Challenge \\
\hline Strategy & $\begin{array}{l}\text { - Collaboration, coordination } \\
\text { and partnership building } \\
\text { limitations }\end{array}$ \\
\hline Implementation & 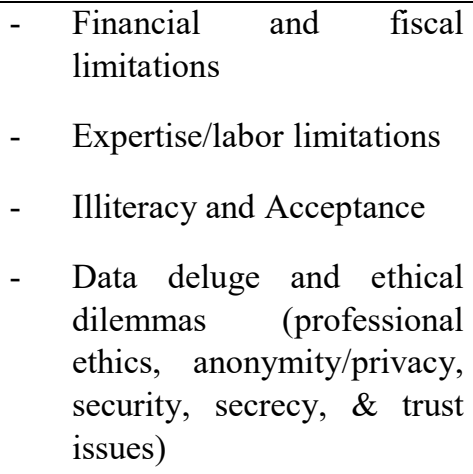 \\
\hline Innovativeness & - $\quad$ The inequality question \\
\hline
\end{tabular}

Sources: Ministry of Finance (2009); European Commission (2015); OECD (2003); OECD (2016); \& OECD (2017).

A key strategic challenge of digital government policy in Finland is related to the issues of collaboration, coordination, and partnership building limitations. According to OECD (2016) and European Commission (2015: 26), the nature of autonomy that exist between the different levels of administration in Finland is a key challenge to e-government policies formulation in Finland. The local governments/administrations, municipalities and regional governments in Finland enjoy a high level of autonomy in both administrative and financial senses. The administrative and financial autonomies make the formulation and updating of general digital government policies in Finland challenging, because different authorities could have different interests at the same time. According to the OECD (2016: 50-51), local governments collects a high share of the general government revenues in Finland, compared to other OECD countries, which is also reflected in the distribution of general government spending. This largely helps them to determine the direction and speed of digitalization of governance, though the act on Information Management Governance in Public Administration allows that the Ministry of Finance has to be consulted when it comes to huge or significant ICT procurement (European Commission 2016: 20).

For the implementation of digital government in relation to public service provision in Finland, finance/money is still a key challenge. The financial and economic crisis has negatively affected the efficiency and effectiveness of e-government implementation in Finland. The implementation challenge is supported by unfriendly and not very transparent fiscal policies and objectives in Finland that often do not put the long run and interest of every stakeholder into consideration. (European Commission 2015 \& OECD 2016.) The inadequate technical expertise that exists in Finland is another challenge to the implementation of digital government in relation to public service provision in Finland. According to University of Vaasa (2018), the ICT sector in Finland suffers from human capacity limitation (labor shortages), which has affected e-government implementation. The issue of digital literacy is another challenge to the implementation of digital government in relation public service provision in Finland. According to Eurostat (2018: 4-7), about 7\% of the Finnish population have difficulties in using e-government tools such as the internet and social media. The problem of digital illiteracy also affects the acceptance of e-government tools at both individual and institutional levels. The challenge of "data deluge" is another challenge that limit e-government implementation in Finland. According to OECD (2016: 35-37), healthcare provision in Nordic states including Finland is affected by data deluge or explosion, because of the huge gap that exists between service supply and feedback from one perspective and management of big or public data from another perspective. The challenge of ethical dilemma in relation professional ethics, anonymity/privacy, security, secrecy, and trust also affect negatively the implementation of egovernment tools; especially, in the areas of democracy and health care provision in Finland (European Commission 2015 \& OECD 2016).

The innovativeness of digital government policy in Finland has not adequately addressed the inequality question that exists in Finland. According to the European Commission (2015: 18-19), the "Government Information Society Programme" has a key objectives of boosting competitiveness and productivity, and promoting social and regional equality through effective utilization of information and communications technologies throughout the society. The value differences that exist between different generations $(\mathrm{X}, \mathrm{Y}$ 
and Z) at work must be included in future modifications of e-government strategies and implementation in Finland (OECD 2016).

\section{CONLUSION}

Digital government as part of public service provision and good governance requirements in Finland has been largely successful; especially, through the e-government framework. Digital government has been defined as part of broader change management and new public management reform ideas in the public sector. Change remains a constant in life and this philosophy has manifested in different perspectives in contemporary administration. Digital government can be summarized as the production and delivery of services and information within government or institution and between government, institution and the public, in order to formulate and implement government/public responsibilities; the two natures of government relationships that exist within this framework are government-to-citizen and government-to-government relationships. The formulation and implementation of public policies and services in Finland have been strongly affected by the growth and use of technological tools. The significance of technology in contemporary administration and governance cannot be overemphasized; especially, as it concerns public institutions and citizens; institutions and execution of public services; and other economic and societal relevance. The case of Finland has revealed from the various reports studied that digital government through the framework of e-government has a good strategic breakdown, action plans and backups.

E-government in Finland is vital to the participation of citizens in aspects of democracy and decision-making; in addition, is helping in health care, education, integration, security, land survey, and social services provision. The implementation of e-government have been enhanced by the development of digital tools at central, regional and municipal governments and institutional levels. The innovativeness of digital government in relation to public service provision essentially concerns scope broadening such as the energy transition. However, after a careful review of different reports on the case of Finland, areas of improvement are still numerous such as improving collaboration, coordination, partnership building between stakeholders, funding, fiscal policies, expertise (labor shortages), literacy level, individual and institutional acceptances. In addition, is addressing the problem of data deluge or explosion and issues relating to ethical dilemmas (e.g. trust and security). Finally, plans relating to future innovations must include ways to address the general inequality questions that exist in Finland.

\section{REFERENCES}

[1] Brunsson, N. 2009. Mechanisms of Hope: Maintaining the Dream of the Rational Organization. Copenhagen: Copenhagen Business School Press.

[2] Fountain, Jane E. 2004. Digital Government and Public Health. Prev. Chronic Dis, Vol. 1(4)

[3] Gavet, Maelle (2017). The Digital Revolution is Destroying our Democracies. It Doen't Have to be That Way. World Economic Forum 2018

[4] Gunter, B. 2006. Advances in E-democracy: Overview. Aslib Journal of Information Management, Vol. 58: 5, 361-370.

[5] Johnson, Craig L. 2007. A Framework for Pricing Government E-service. Electronic Commerce Research and Applications, Vol. 6, Issue 4

[6] Khan, S. 2016. Leadership in the Digital Age: A Study on the Effects of Digitalisation on Top Management Leadership. Stockholm University, 54.

[7] M. Young, The Technical Writer's Handbook. Mill Valley, CA: University Science, 1989.

[8] Peters, B. Guy. 2001. The Future of Governing. Kansas: University Press of Kansas.

[9] Riley, B. Riley. 2003. E-Government vs. EGovernance: Examining the Difference in a Changing Public Sector Climate. International Tracking Survey Report'03 Number Four, 1-29.

[10] Simon, A. Herbert. 1997. Administrative Behaviour. U.S.A: Simon and Schuster Inc.

[11] Tickner, Peter (2015). Fraud and Corruption in Public Service. Surrey: Gower Publishing Limited

\section{Other Used Materials}

(1) European Commission. 2015. eGovernment in Finland. Publications Services: Brussels

(2) European Police Office. 2017. "Serious and Organized Crime Threat Assessment: Crime in the Age of Technology," EUROPOL

(3) Eurostat 2018. Individuals Using the Internet for Interacting with Public Authorities. Available on the Internet 01-02-2018: http://appsso.eurostat.ec.europa.eu/nui/show.do? dataset $=$ isoc_bde15ei\&lang $=$ en

(4) Global Security.org (2017). Italy: Corruption Global Security Organization: Grandville.

(5) Ministry of Finance. 2009. Final Project Report for SADe: Development Plans and Action Plan for eServices and Administration between 2009 . 2012. Publication Services: Helsinki

(6) OECD. 2016. OECD Comparative Study: Digital Government Strategies for Transforming Public Services in the Welfare Areas. Publications Services. Paris

(7) OECD. 2017. Highlights from the OECD Science, Technology and Industry Scoreboard 2017-The Digital Transformation: Finland. Available on the Internet 03-01-2018 https://www.oecd.org/finland/sti-scoreboard2017-finland.pdf

(8) University of Vaasa (2018). Vaasan Yliopistolle 455,000 Euroa ICT-Muutokouluksen Järjestämiseen. Available on the Internet 19-012018: http://www.uva.fi/fi/news/ict muuntokoulutus/ 